\title{
Protective effect of Photobiomodulation Therapy and Bone Marrow Stromal Stem Cells Conditioned Media on Pheochromocytoma Cell Line 12 Against Oxidative Stress Induced by Hydrogen Peroxide
}

\author{
Shahrokh Khoshsirat ${ }^{1}$, Hojjat Allah Abbaszadeh ${ }^{1,2,3 *}$, Maryam Sadat Khoramgah ${ }^{2,4}$, Shahram Darabi ${ }^{5}$, Vahid \\ Mansouri' ${ }^{6}$, Navid Ahmady-Roozbahany ${ }^{7}$, Behnaz Ahrabi' ${ }^{2}$, Maryam Bahrami², Saeed Vafaei-Nezhad ${ }^{2,3}$, \\ Foozhan Tahmasebinia ${ }^{8}$, Mahnaz Poor Hassan ${ }^{2,3}$ \\ ${ }^{1}$ Hearing Disorders Research Center, Loghman Hakim Hospital, Shahid Beheshti University of Medical Sciences, Tehran, \\ Iran \\ ${ }^{2}$ Laser Application in Medical Sciences Research Center, Shahid Beheshti University of Medical Sciences, Tehran, Iran \\ ${ }^{3}$ Department of Biology and Anatomical Sciences, School of Medicine, Shahid Beheshti University of Medical Sciences, \\ Tehran, Iran \\ ${ }^{4}$ Department of Biotechnology, School of Advanced Technologies in Medicine, Shahid Beheshti University of Medical \\ Sciences, Tehran, Iran \\ ${ }^{5}$ Cellular and Molecular Research Center, Qazvin University of Medical Science, Qazvin, Iran \\ ${ }^{6}$ Faculty of Paramedical Science, Proteomics Research Center, Shahid Beheshti University of Medical Sciences, Tehran,Iran \\ ${ }^{7}$ G. Raymond Chang School, Ryerson University, Toronto, Canada \\ ${ }^{8}$ Department of Biological Sciences, Institute for Advanced Studies in Basic Sciences (IASBS), Zanjan, Iran
}

\section{*Correspondence to \\ Hojjat-Allah Abbaszadeh, Hearing \\ Disorders Research Center and \\ Department of Biology and \\ Anatomical Sciences, school \\ of medicine, Shahid Beheshti \\ University of Medical Sciences, \\ Tehran, Iran. P.O.Box: 19395-4719. \\ Tel: +98-21-23872555; \\ Fax: +98-21-22439976 \\ Email: Dr.abbaszadeh79@gmail. \\ com, Dr.abbaszadeh@sbmu.ac.ir}

Published online July 6, 2019

\begin{abstract}
Introduction: Bone marrow stromal stem cells (BMSCs), a type of adult stem cells, secrete bioactive molecules such as trophic factors, growth factors, chemokine and cytokines that may be effective against oxidative stress in neurodegenerative diseases.

In this study, we examined the protective effect of BMSCs conditioned media (CM) and photobiomodulation therapy (PBMT) on PC12 cells exposed to $\mathrm{H} 2 \mathrm{O} 2$ as an oxidative injury model.

Methods: BMSCs were cultured and confirmed by flow cytometry analysis and underwent osteogenic and adipogenic differentiation. Then, $\mathrm{PC} 12-\mathrm{H} 2 \mathrm{O} 2$ cells were co-treated with BMSCs-CM and PBMT. The effect of BMSCs-CM and PBMT (He-Ne laser, $632.8 \mathrm{~nm}, 3 \mathrm{~mW}, 1.2 \mathrm{~J} /$ $\mathrm{cm}^{2}, 378 \mathrm{~s}$ ) on $\mathrm{Bax} / \mathrm{Bcl} 2$ expression, cell viability, was assessed by real-time PCR and MTT assay. The length of the Neurite and cell body areas were assessed by Cell A software.

Results: Flowcytometry analysis, as well as osteogenic and adipogenic staining, confirmed the BMSCs. The length of the Neurite was the highest in the group which received CM+PBMT and cell body areas were significant in CM+PBMT compared to other groups. Based on our results, elevating $\mathrm{H} 2 \mathrm{O} 2$ concentration increased cell death significantly and using concentrations of $250 \mu \mathrm{M}$ resulted in a dramatic increase in the mortality compared to the other groups.

Conclusion: Our result demonstrated that the combination of $\mathrm{CM}+\mathrm{PBMT}$ has a protective effect on PC12 cells against oxidative stress.

Keywords: BMSCs; PC12 cells; Hydrogen peroxide; PBMT.
\end{abstract}

\section{Introduction}

There is increasing evidence that reactive oxygen species (ROS) such as free radicals and hydrogen peroxide $(\mathrm{H} 2 \mathrm{O} 2)$ are involved in the pathophysiology of neurodegenerative disorders. ${ }^{1}$ One of the major culprits of oxidative modification, damage to macromolecules such as DNA, and also oxidative stress is $\mathrm{H} 2 \mathrm{O} 2$ which is produced during the redox reactions. It could change normal cellular functions and integrity. ${ }^{2,3}$ In fact, the oxidant/antioxidant level is critical in neurodegeneration or neuroprotection. The oxidant/antioxidant imbalance may lead to neuronal apoptosis, but exact mechanisms underlying it are not completely understood. Neuroprotection could be guaranteed by several antioxidant enzymes inside cells, for instance, superoxide dismutase (SOD) which constitutes critical antioxidant defense. ${ }^{4,5}$ Previous studies pointed

Please cite this article as follows: Khoshsirat S, Abbaszadeh HA, Khoramgah MS, et al. Protective effect of photobiomodulation therapy and bone marrow stromal stem cells conditioned media on pheochromocytoma cell line 12 against oxidative stress induced by hydrogen peroxide. J Lasers Med Sci. 2019;10(3):163-170. doi:10.15171/jlms.2019.26. 
out that an elevated level of $\mathrm{H} 2 \mathrm{O} 2$ in neuronal cells can alter the gene expression, the mitochondrial function and the mitochondrial permeability transition pore, ${ }^{6,7}$ which ultimately could induce apoptosis. Therapeutic strategies aimed at suppressing apoptosis signaling pathways switched on by ROS might be promising for the treatment of neurodegenerative diseases. ${ }^{8,9}$ Pheochromocytoma cell line 12 (PC12) is widely used as a classical cell model for studying neurons from the biochemical aspect. $\mathrm{H} 2 \mathrm{O} 2$ may induce apoptosis in PC12 cells. ${ }^{10,11}$ According to stem cell studies, bone marrow stromal stem cell (BMSC) and adipose stem cells (ADSCs) have been found promising for the treatment of neurodegenerative disorders. ${ }^{12,13}$ Actually, it is well documented that the systemic administration of mesenchymal stem cells (MSCs) derived from different tissues is neuroprotective. Neuroprotective effects of these cells may be mediated by secretion of bioactive molecules such as trophic factors, growth factors, chemokine, cytokines, and extracellular microvesicles, which can enhance cell survival. BMSCs condition medium (CM) contains IGF-1, VEGF, TGF $\beta 1$, GDNF, FGF-2, BDNF, and HGF, and it has been reported by Cantinieaux et al that BMSC-CM has several different properties such as antiapoptotic, proinflammatory, and angiogenic properties and can enhance the outgrowth of axons through the glial scar. ${ }^{14,15}$ Recently, the laser has been proposed for the treatment of neurological diseases based on its positive effects on the nervous system, particularly the reduction of oxidative effects. ${ }^{16}$ Not only does photobiomodulation therapy (PBMT) reduce the harmful effects of $\mathrm{H} 2 \mathrm{O} 2$, but also it increases the expression of antioxidants and reduces oxidative stress. ${ }^{17}$ Nerve regeneration and tissue healing are positively affected by low-energy lasers. These lasers support chiropractic interventions in an effective way. When the wavelength falls in the red and near-infrared ranges, the laser has low energy and cannot cause any type of biomolecular ionization and subsequent damage. The application of PBMT is able to decrease or prevent this phenomenon. ${ }^{18}$ In addition, there is an improvement in the quality of the regeneration as well as the recovery time. The enhancement of the recovery in the injured nerves was followed by the application of PBMT which resulted in an improvement of the nerve function and also a significant overall functional recovery. The neural lesion could be another area in which laser therapy could be used effectively. ${ }^{19}$ Patients with different types of neural lesions without responding to conservative treatment have shown signs of improvement after treatment with high doses of the laser applied to the site of the lesion. Thus, it can be suggested that PBMT can promote the neural function recovery by repairing or preventing the extensive degenerative changes. ${ }^{20,21}$ In this study, we examined the protective effect of BMSCs-CM and PBMT on $\mathrm{PC} 12$ cells exposed to $\mathrm{H} 2 \mathrm{O} 2$ as an oxidative injury model.

\section{Materials and Methods}

Bone Marrow Stromal Cell Extraction, Culturing and CM Preparation

After being anesthetized with an intraperitoneal injection of ketamine and diazepam, female Wistar rats (Razi Institute for Serums and Vaccine, Karaj, Iran) were euthanized. The BMSCs were extracted from rats' femurs by 18-gauge syringe and cultured in DMEM/F12 (Stem Cell Technology Company, Tehran, Iran) $+10 \%$ FBS (Sigma, USA), $100 \mathrm{u} / \mathrm{mL}$ penicillin (PC) (Sigma,USA), $100 \mathrm{mg} / \mathrm{mL}$ streptomycin (SP) (Sigma,USA). For preparing the BMSCs-CM, the fourth passage of BMSCs was used. Upon reaching $80 \%$ confluence, the cells were washed three times using PBS (Sigma, USA). The current media were replaced by serum-free DMEM/F12 (Stem Cell Technology Company, Tehran, Iran) as a new media. Lyophilized-drying was used to concentrate CM 20 fold in accordance with the company's instructions. ${ }^{22,23}$

Flow Cytometry Analysis and Osteogenic and Adipogenic Differentiation

Flowcytometry (Becton Dickinson, USA) was performed for detecting CD105, CD90 (positive marker) and CD31, CD45 (negative marker) on cells at the very same time in order to define cell subsets based on lineage. The Cells were labeled with fluorochrome-conjugated antibodies and then analyzed by flow cytometry. For the purpose of inducing the osteogenic differentiation, $1 \times 10^{6} \mathrm{cells} / \mathrm{cm}^{2}$ were plated in osteogenic media (Royan Institute, Iran). We stained the cultured cells with Alizarin red (SigmaAldrich, St. Louis, MO) in order to reveal the osteogenic differentiation. To achieve the adipogenic differentiation, $1 \times 10^{6}$ cells $/ \mathrm{cm}^{2}$ were cultured in adipogenic media (Royan Institute, Iran). After 3 weeks, we fixed and stained them by oil (Sigma-Aldrich, St. Louis, MO) red and analyzed them by microscope.

\section{PBMT Administration}

We used the IR laser (Mustang 2000; Technical Co., Moscow, Russia), the specifications of which are shown below (see Table 1). In the present study, the pulse wave (PW) parameters of PBM were used effectively. One day after incubation by $\mathrm{H} 2 \mathrm{O} 2$, PBMT initiated, 3 times a week for the period of two weeks. ${ }^{18}$

\section{PC12 Cell Culture and Treatment}

The PC12 cells line were seeded within DMEM/F12 medium supplemented with $10 \%$ FBS, PC (1\%) and SP (1\%). After culturing cells, they were treated with $\mathrm{H} 2 \mathrm{O} 2$ $(0,25,50,75,100,150,200,250 \mu \mathrm{M})$ for 12 hours. ${ }^{23}$ Finally, the cells were exposed with BMSC-CM (4:1 ratio of CM) and PBMT.

\section{Examination of PC12 Cell Morphology}

After seeding PC12 cells in plates, 20 random images, in total, were obtained from each well for morphological 
Table 1. The Specifications of the Used Laser

\begin{tabular}{lc}
\hline Parameters & Dose and Unit \\
\hline Peak power output & $80 \mathrm{~W}$ \\
Average power & $1.15 \mathrm{~mW}$ \\
Power density & $1.15 \mathrm{~W} / \mathrm{cm}^{2}$ \\
Wavelength & $890 \mathrm{~nm}$ \\
Pulse frequency & $80 \mathrm{~Hz}$ \\
Spot size & $1 \mathrm{~cm}^{2}$ \\
Pulsed duration & $180 \mathrm{~ns}$ \\
Energy density (ED) & $1.5 \mathrm{~J} / \mathrm{cm}^{2}$ \\
The shape of the laser beam & Circular \\
The frequency of treatment & 3 times a week \\
\hline
\end{tabular}

analytical purposes. We assessed the cell body area and the neurite length after administration of PBMT and CM. In this study, the neurite length is the area covered by the cells as previously reported and the sum of the lengths of all primary branches and their associated twigs. ${ }^{24}$

\section{MTT Assay}

The PC12 cells were seeded and treated on 96-well plate, and MTT (Sigma-Aldrich, St. Louis, MO) assay was performed on each well. After 4-hour incubation, the Medium was removed, the absorption spectrum of the suspension was obtained around $590 \mathrm{~nm}$, and cell viability was measured and reported as the percentage of control cells. ${ }^{22}$

Real-Time Polymerase Chain Reaction

In order to determine the abundance of gene transcripts including Bax and Bcl2, total RNA was collected from the removed spine in one week using RNA extraction kit (Invitrogen, USA) according to the kit protocol. We prepared the cDNAs by the Prime Script TM RT reagent Kit (Fermentas, Lithuania). Reverse transcription was carried out using a 96-well real-time polymerase chain reaction (PCR) instrument with SYBR dye-based master mix (Applied Biosystems, USA). Initial denaturation was performed at $95^{\circ} \mathrm{C}$ for 30 seconds, annealing for $45 \mathrm{sec}$, extension at $72^{\circ} \mathrm{C}$ for 45 seconds and a final polymerization at $65^{\circ} \mathrm{C}$ for 10 minutes. The primer sequences and annealing temperature are briefed in Table 2. We applied the comparative Ct method for gene target expression analysis $(2 \Delta \Delta \mathrm{Ct}){ }^{18}$ All samples were normalized with GAPDH level, as the loading control.

\section{Cell Viability Assay}

Using the EukolightTM Viability/Cytotoxicity assay (Molecular Probes), we distinguished living and dead cells. The medium was changed using $4 \mathrm{mM}$ ethidium homodimer-1 and $2 \mathrm{mM}$ calcein acetoxymethyl ester (Sigma-Aldrich, St. Louis, MO). The Images of 20 random microscopic fields were used to count the number of viable and non-viable PC12 cells. ${ }^{23}$

\section{Data Analysis}

A one-way analysis of variance (ANOVA) along with the Tukey posthoc test was performed for statistical analysis. The data were expressed as mean \pm SEM and statistically significant data had a $P$ value $<0.05$.

\section{Results}

Identification of BMSCs

A few hours after the initial culture of BMSCs, they began to attach to the flask and showed a round form. 12 hours later, they were characterized as dense fibroblast-like cell colonies (Figure 1). Flow cytometry results showed that these cells are positive for CD105 and CD90 markers and negative for CD45 and CD31, which confirmed the stem cell identity (Figure 1). In addition, in order to investigate the differentiation potential of the cultured cells, they were treated by osteogenic and adipogenic mediums. The staining of the adipose-differentiated group with oil red revealed the presence of fat droplets among the differentiated cells (Figure 1), and the presence of calcified sediment using Alizarin red staining between the osteogenic differentiated cells proved the osteogenic differentiation of these cells (Figure 1).

The Morphological Characteristics of PC12 Cells After Treatment With PBMT and CM

As previously mentioned, for examining the morphological characteristics of the cells, numerous images were captured from each well in all groups [control and different concentrations of $\mathrm{H} 2 \mathrm{O} 2](0,25,50,75,100$, $150,200,250 \mu \mathrm{M})$ and at least50 cells were randomly examined in each group. Assessment of the results using Cell A program revealed that after exposing the cells to $\mathrm{H} 2 \mathrm{O} 2$ for 12 hours and treatment with $\mathrm{CM}+$ PBMTthe length and width of the neurite and cell body area were the highest in the group that received CM+PBMT. These measurements were lower in the group that was treated with CM (Figures 2 and 3).

Table 2. Primer Sequences Used in the qRT-PCR

\begin{tabular}{|c|c|c|c|c|}
\hline GENE & Primer Type & Sequence & Annealing Temperature & Product size (Base Pairs) \\
\hline Bax & $\begin{array}{l}\mathrm{F} \\
\mathrm{R}\end{array}$ & $\begin{array}{l}\text { CCCGAGAGGTCTTTTTCCGAG } \\
\text { CСАGСCСАTGATGGTTCTGAT }\end{array}$ & 65 & 210bp \\
\hline$B C l 2$ & $\begin{array}{l}\mathrm{F} \\
\mathrm{R}\end{array}$ & $\begin{array}{l}\text { TACAGGCTGGCTCAGGACTAT } \\
\text { CGCAACATTTTGTAGCACTCTG }\end{array}$ & 65 & 230bp \\
\hline GAPDH & $\begin{array}{l}\mathrm{F} \\
\mathrm{R}\end{array}$ & $\begin{array}{l}\text { CCACAACTC TTCCATTCTC } \\
\text { CCAAGATTCACGGTAGATAC }\end{array}$ & 59 & 200bp \\
\hline
\end{tabular}



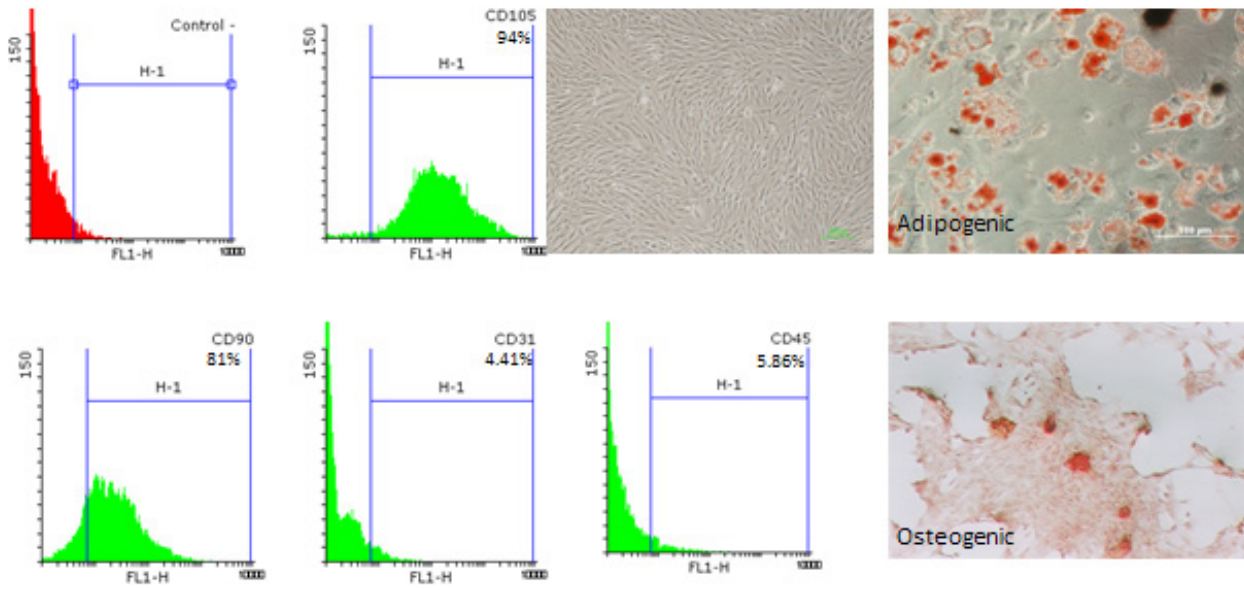

Figure 1. Phase Contrast, Adipogenic and Osteogenic Differentiation in BMSC. Flowcytometry CD marker analyses of BMSC shows were positive for CD105, CD90 and negative for CD45, CD 31.

Assessment of H2O2-Induced Cell Death in Different Groups

As the PC12 cells were treated with dose-response of $\mathrm{H} 2 \mathrm{O} 2(0,25,50,75,100,150,200,250 \mu \mathrm{M})$ for 12 hours, the apoptosis rate was assessed using the MTT kit. The results presented that increasing $\mathrm{H} 2 \mathrm{O} 2$ concentration significantly increased cell death. In addition, the mortality rate rose dramatically after using concentrations of $250 \mu \mathrm{M}$ in comparison with the other groups. However, in all three groups, there was a remarkable reduction in survival compared to the control group (Figure 4).

The Effect of CM+ PBMT on the Cell Body Area and Neuritis Length of the PC12 Cells After H2O2 Induction Analyzing images using the Cell A program showed that $\mathrm{CM}+\mathrm{PBMT}$ has a considerable role in reducing the cell body area in different groups in comparison with those that were only affected by $\mathrm{H} 2 \mathrm{O} 2$. Additionally,
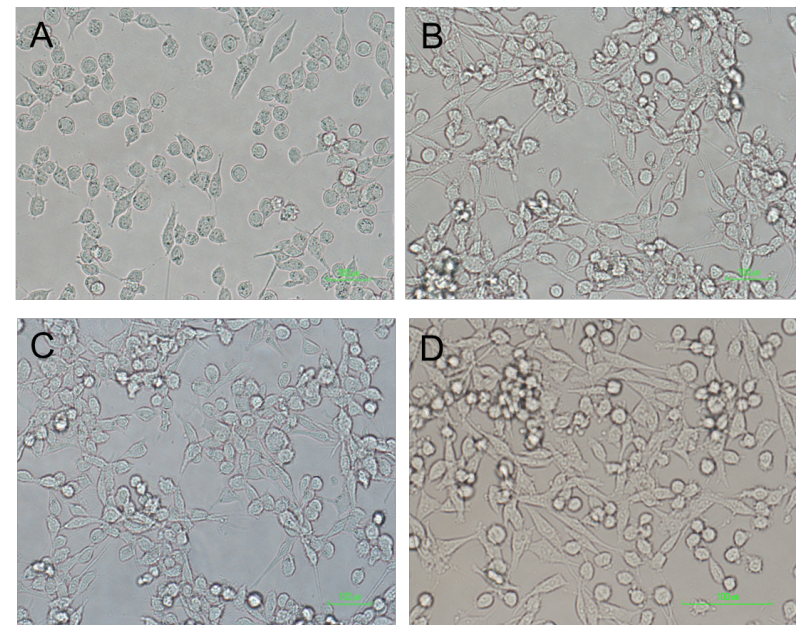

Figure 2. Morphology of $\mathrm{PC} 12$ Cell Line After Treatment by CM, PBMT, CM+PBMT. PC12+H202 (A), PC12+H202+CM (B), $\mathrm{PC} 12+\mathrm{H} 2 \mathrm{O} 2+\mathrm{PBM}(\mathrm{C}), \mathrm{PC} 12+\mathrm{H} 2 \mathrm{O} 2+\mathrm{PBMT}+\mathrm{CM}(\mathrm{D})$.
$\mathrm{CM}+\mathrm{PBMT}$, compared to the control group, reduced the amount of cell body area significantly by acting on the cells that were affected by $\mathrm{H} 2 \mathrm{O} 2$-induced oxidative stress. Moreover, comparing the results of the PBMT $+\mathrm{CM} / \mathrm{H} 2 \mathrm{O} 2$ treated group with a group which was only exposed to $\mathrm{H} 2 \mathrm{O} 2$ revealed that $\mathrm{PBMT}+\mathrm{CM}$ plays a significant role in increasing neuritis length compared to the control group (Figures 5 and 6).

Effect of CM+PBMT on the Apoptosis Rate and the BAX/ BCL2 Ratio in $\mathrm{H} 2 \mathrm{O} 2$-Treated Cells

The results of real-time PCR analysis showed the Bax/ $\mathrm{Bcl} 2$ ratio decreased in $\mathrm{CM}+\mathrm{PBMT}$ compared to the control group (Figure 7). The results of the assessment of cell viability and survival in different groups showed that $\mathrm{CM}+\mathrm{PBMT}$ remarkably increased the survival of the $\mathrm{H} 2 \mathrm{O} 2$-treated cells compared to the cells that were only exposed to $\mathrm{H} 2 \mathrm{O} 2$. Real-time PCR results also confirmed this and the analysis of its outcome

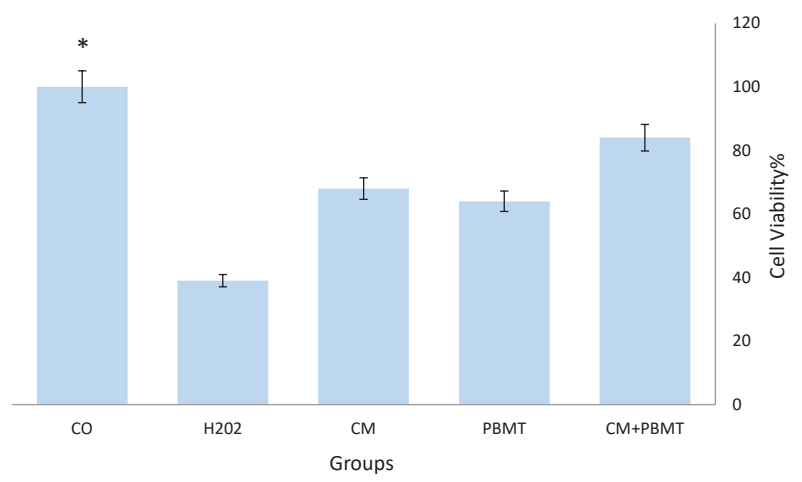

Figure 3. Effect of $C M, P B M T$, and $C M+P B M T$ on Cell Viability. $\mathrm{CM}, \mathrm{PBMT}$, and $\mathrm{H} 2 \mathrm{O} 2$ were added to $\mathrm{PC} 12$. After $12 \mathrm{~h}$, cell viability was examined by MTT assay. Viability was calculated as the percentage of living cells in treated cultures compared to control cultures. ${ }^{*} P<0.5$. 


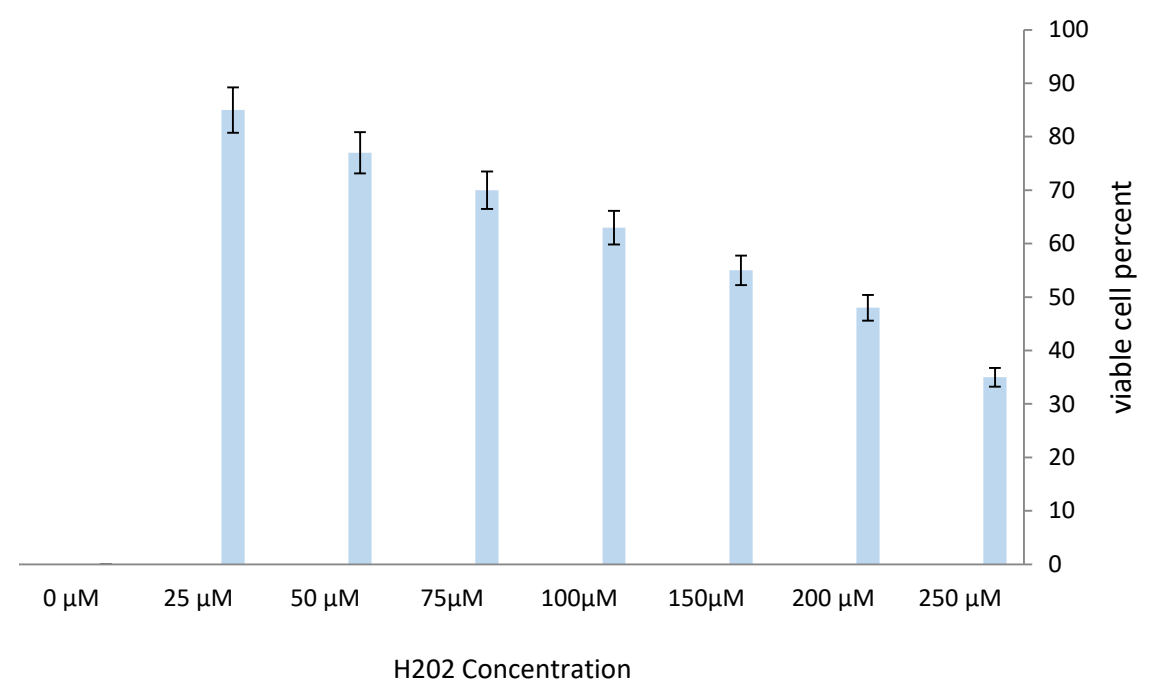

Figure 4. Dose-Dependent Cell Death Induced by $\mathrm{H} 2 \mathrm{O} 2$ in PC12 Cell Line. Cell viability was examined by MTT assay. The survival rate after $12 \mathrm{~h}$ was $35,48,55,63,70,77$ and $85 \%$ of the control group in the group receiving 25,50, 75, 100,150, 200 and $250 \mu \mathrm{M}$ of $\mathrm{H} 2 \mathrm{O} 2$ respectively.

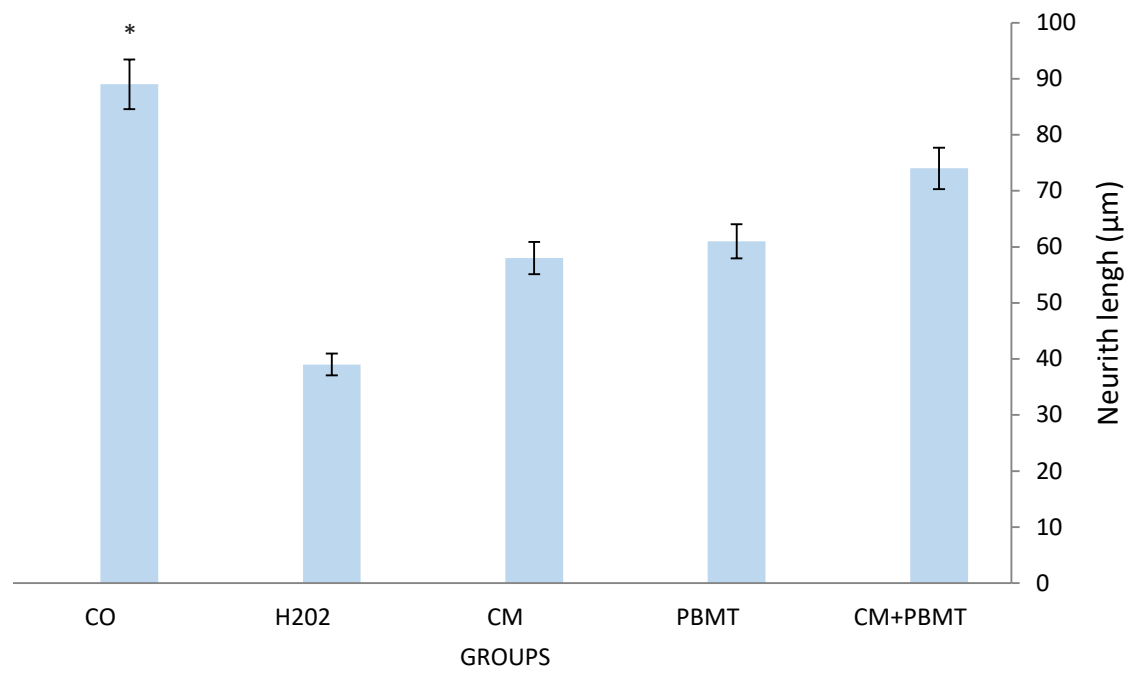

Figure 5. Effect of $\mathrm{CM}, \mathrm{PBMT}, \mathrm{CM}+\mathrm{PBMT}$ on the PC12 Neurite length was defined as the sum of lengths of all primary branches and their associated twigs. ${ }^{*} P<0.05$ significant different from $\mathrm{H} 2 \mathrm{O} 2$ groups.

showed that CM+PBMT significantly contributed to the reduction of apoptosis due to oxidative stress caused by $\mathrm{H} 2 \mathrm{O} 2$ (Figure 7).

\section{Discussion}

The results of our experimental study showed that the combination of PBMT and CM has a protective effect on the $\mathrm{PC} 12$ cells against $\mathrm{H} 2 \mathrm{O} 2$. In fact, the BMSCs have already been used to treat neurodegenerative diseases due to their secretions such as trophic factors, growth factors, chemokines, cytokines, and extracellular microvesicles. Furthermore, BMSCs can be successfully differentiated into different types of glial cells. ${ }^{22,23}$ In this study, the
PC12 cells showed the morphology of nerve-like cells. First, they were exposed by various doses of $\mathrm{H}_{2} \mathrm{O} 2$ (50, $100,150,250 \mu \mathrm{M}$ for 24 hours) and then Cell body area and Neurite length were measured. A study by Ghorabi et al. showed that the treatment of cells with $\mathrm{H}_{2} \mathrm{O}_{2}$ not only increased Cell body area but also decreased Neurite length, which is consistent with our findings. ${ }^{24}$ In our study, the viability of the PC12 cells was assessed using the MTT assay as well. Clementi et al. displayed that the use of $\mathrm{H}_{2} \mathrm{O}_{2}(250 \mu \mathrm{M}$ for 24 hours) reduced the viability of the PC12 cells; the results of our study were also consistent with their findings. ${ }^{25}$ We used PC12 cell line for several reasons. The PC12 cells and the sympathetic 


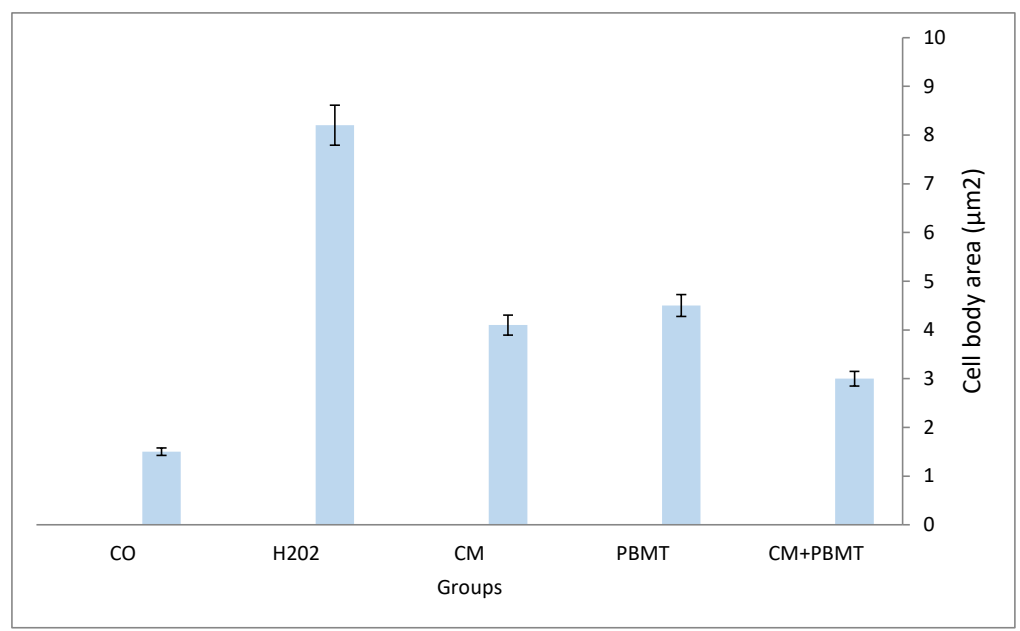

Figure 6. Effect of H2O2, CM, PBMT, CM+PBMT on the PC12 Cells Morphology, The area of a cell body except its branches was defined as cell body area.

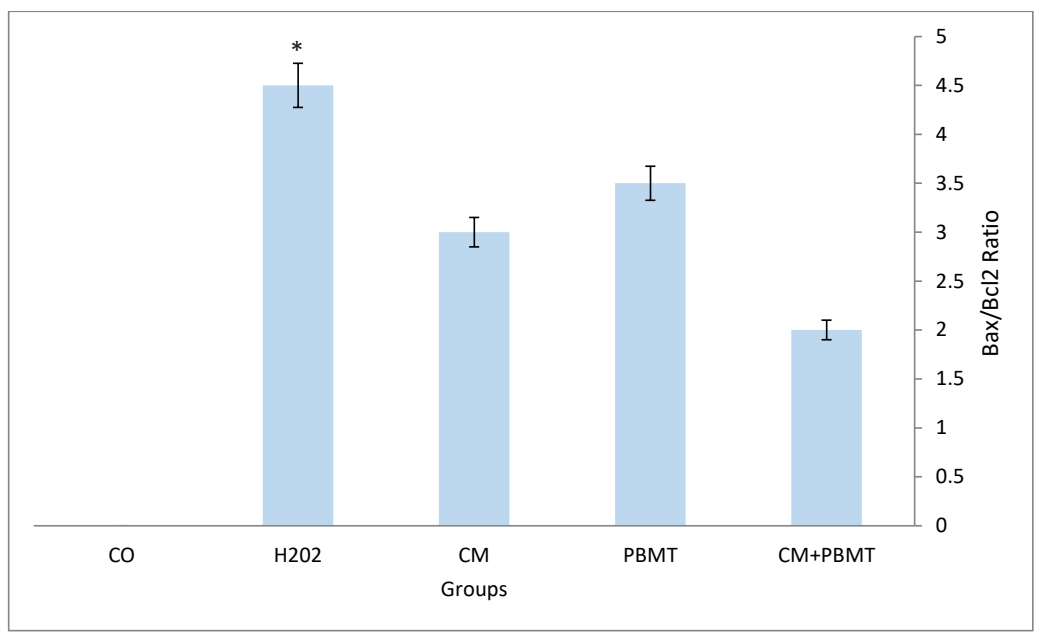

Figure 7. The $\mathrm{Bax} / \mathrm{Bcl} 2$ Ratio in the Control and Experimental Groups. The Bax/Bcl2 ratio in the $\mathrm{CM}+\mathrm{PBMT}$ group decreased in comparison with the other groups. ${ }^{*} P<0.05$.

ganglionic cells have a similar phenotype. In our study, the PC12 cells showed the morphology of nerve-like cells. In fact, the high cost and also the conditions required for hardening neurons in the laboratory conditions restrict the application of neurons. Also, during nerve isolation, adult nerve tissues are often damaged. On the other hand, the PC12 cells have high passage capability and they are the best source of cells for studying the physiology and pathology of the nervous system. The PC12 cells are used in neurodegenerative disease models due to their easiness in their proliferation and differentiation. ${ }^{26}$ In addition, hypoxia is considered as one of the reasons for developing neurodegenerative diseases which cause damage to the neural tissue and impair the function of the nervous system. ${ }^{27}$ Since hypoxia can lead to ischemia of neuronal cells, PC12 cells are most often used in hypoxia studies. ${ }^{28}$ Recent studies have shown that ROS increases in many neurodegenerative diseases. ${ }^{29,30}$ An increased level of
$\mathrm{H} 2 \mathrm{O} 2$ followed by an increased ROS level occurs when the ROS production exceeds the number of antioxidants that are produced within the cells, resulting in oxidative stress in the cells and causing mitochondrial dysfunction and neuronal death. ${ }^{31,32}$ In neurodegenerative diseases, changes in neurons can cause sensory and/or motor deficits. Therefore, it is important to find a way to prevent apoptosis in neurons. ${ }^{33,34}$ In this study, we focused on the neuroprotective effects of PBMT and BMSC-CM. We investigated the $\mathrm{Bax} / \mathrm{Bcl} 2$ ratio for evaluation of apoptosis by the real-time PCR technique in different groups. In our study, $\mathrm{H}_{2} \mathrm{O}_{2}$ induced apoptosis decreased the expression of the $\mathrm{Bcl} 2$ gene and increased the expression of the Bax gene. We used CM and PBMT for the treatment of the PC12 cells induced by $\mathrm{H}_{2} \mathrm{O}_{2}$. Due to neuroprotective effects, the viability of the PC12 cells increased significantly, the expression of the $\mathrm{Bcl} 2$ gene increased, and the expression of the Bax gene decreased. A study by Res et al. proved that 
the use of BMSCs and their microvesicles can reduce the toxicity of glutamate in the PC12 cells by increasing the expression of $\mathrm{Bcl} 2$ and decreasing the expression of $\mathrm{Bax}$ and caspase 3. These results are confirmed by our study as well. ${ }^{35}$ In this study, PBMT had a positive effect on the reduction of oxidative stress as well as the improvement of the morphological markers of the PC12 cells. Based on several reports, PBMT can promote energy metabolism within the mitochondria. It can also accelerate the process of cell division. ${ }^{36,37}$ Besides an increased blood flow, another effect of this laser, all these effects will promote neuronal recovery. ${ }^{38}$ In a study on animal models, after treating the hemisected spinal cords with an 810-nm laser, the cell invasion became blocked immediately in the treatment group, however, the damaged axons began to sprout after 14 days and there was an increase in the invasion of non-inflammatory cells and cell division. It is proposed that the acceleration in the activities inside the spinal cord environment may be the reason for the effects the laser has on axonal regeneration. ${ }^{39}$

\section{Conclusion}

The combination of $\mathrm{CM}+\mathrm{PBMT}$ has a protective effect on the $\mathrm{PC} 12$ cells against $\mathrm{H}_{2} \mathrm{O}_{2}$.

\section{Ethical Considerations}

This study have been approved by ethical committee of Shahid Beheshti University of Medical Sciences.

\section{Conflict of Interests}

The authors declare no conflict of interest.

\section{Acknowledgment}

This work was supported by grant of the Hearing Disorders Research Center of Shahid Beheshti University of Medical Sciences, Tehran, Iran. We would like to thank Clinical Research Development Center of Loghman Hakim hospital, Tehran, Iran.

\section{References}

1. Naderi MS, Razzaghi M, Esmaeeli Djavid G, Hajebrahimi Z. A comparative study of $660 \mathrm{~nm}$ low-level laser and light emitted diode in proliferative effects of fibroblast cells. $J$ Lasers Med Sci. 2017;8(Suppl 1):S46-S50. doi: 10.15171/ jlms.2017.s9.

2. Tang XQ, Feng JQ, Chen J, et al. Protection of oxidative preconditioning against apoptosis induced by $\mathrm{H} 2 \mathrm{O} 2$ in PC12 cells: mechanisms via MMP, ROS, and Bcl2. Brain Res. 2005;1057(1-2):57-64. doi:10.1016/j. brainres.2005.07.072

3. Lou H, Jing X, Ren D, Wei X, Zhang X. Eriodictyol protects against $\mathrm{H} 2 \mathrm{O} 2$-induced neuron-like $\mathrm{PC} 12$ cell death through activation of Nrf2/ARE signaling pathway. Neurochem Int. 2012;61(2):251-257. doi:10.1016/j.neuint.2012.05.013

4. Cao Y, Liu JW, Yu YJ, et al. Synergistic protective effect of picroside II and NGF on PC12 cells against oxidative stress induced by H2O2. Pharmacol Rep. 2007;59(5):573-579.
5. Siddiqui MA, Kashyap MP, Kumar V, et al. Differential protection of pre-, co- and post-treatment of curcumin against hydrogen peroxide in PC12 cells. Hum Exp Toxicol. 2011;30(3):192-198. doi:10.1177/0960327110371696

6. Hwang SL, Yen GC. Neuroprotective effects of the citrus flavanones against $\mathrm{H} 2 \mathrm{O} 2$-induced cytotoxicity in $\mathrm{PC} 12$ cells. J Agric Food Chem. 2008;56(3):859-864. doi:10.1021/ jf072826r

7. Zhang Q, Huang WD, Lv XY, Yang YM. Puerarin protects differentiated $\mathrm{PC} 12$ cells from $\mathrm{H} 2 \mathrm{O} 2$-induced apoptosis through the PI3K/Akt signalling pathway. Cell Biol Int. 2012;36(5):419-426. doi:10.1042/cbi20100900

8. $\mathrm{Hu} \mathrm{Y,} \mathrm{Lv} \mathrm{X,} \mathrm{Zhang} \mathrm{J,} \mathrm{Meng} \mathrm{X.} \mathrm{Comparative} \mathrm{Study}$ on the Protective Effects of Salidroside and Hypoxic Preconditioning for Attenuating Anoxia-Induced Apoptosis in Pheochromocytoma (PC12) Cells. Med Sci Monit. 2016;22:4082-4091.

9. Jiang B, Liu JH, Bao YM, An LJ. Catalpol inhibits apoptosis in hydrogen peroxide-induced PC12 cells by preventing cytochrome $\mathrm{c}$ release and inactivating of caspase cascade. Toxicon. 2004;43(1):53-59. doi:10.1016/j. toxicon.2003.10.017

10. Firouzi A, Fadaei Fathabadi F, Norozian M, Amini A, Abdollahifar MA, Noruzian M. The combined effects of levothyroxine and low level laser therapy on wound healing in hypothyroidism male rat model. J Lasers Med Sci. 2018; 9(1):7-10. doi:10.15171/jlms.2018.02.

11. Cheng XR, Zhang L, Hu JJ, Sun L, Du GH. Neuroprotective effects of tetramethylpyrazine on hydrogen peroxideinduced apoptosis in PC12 cells. Cell Biol Int. 2007;31(5):438-443. doi:10.1016/j.cellbi.2006.10.001

12. Darabi S, Tiraihi T, Noorizadeh A, Rajaei F, Darabi L, Abbaszadeh $\mathrm{H}$. Creatine and retinoic acid effects on the induction of autophagy and differentiation of adipose tissue-derived stem cells into GABAergic-like neurons. Journal of Babol University of Medical Sciences. 2017;19(8):41-49. doi:10.22088/jbums.19.8.41

13. Chang KA, Kim HJ, Joo Y, Ha S, Suh YH. The therapeutic effects of human adipose-derived stem cells in Alzheimer's disease mouse models. Neurodegener Dis. 2014;13(2-3):99102. doi: $10.1159 / 000355261$

14. Abbaszadeh HA, Tiraihi T, Delshad A, et al. Differentiation of neurosphere-derived rat neural stem cells into oligodendrocyte-like cells by repressing PDGF- $\alpha$ and Olig2 with triiodothyronine. Tissue Cell. 2014;46(6):462-469. doi:10.1016/j.tice.2014.08.003.

15. Uccelli A, Benvenuto F, Laroni A, Giunti D. Neuroprotective features of mesenchymal stem cells. Best Pract Res Clin Haematol. 2011;24(1):59-64. doi:10.1016/j. beha.2011.01.004

16. Nakano N, Nakai Y, Seo TB, et al. Characterization of conditioned medium of cultured bone marrow stromal cells. Neurosci Lett. 2010;483(1):57-61. doi:10.1016/j. neulet.2010.07.062

17. Leonardo L. Nonsurgical Laser Treatment (NSLT) of Central and Peripheral Nervous System Injuries. Photomed Laser Surg. 2017;35(4):181-183. doi:10.1089/pho.2016.4259

18. Mohsenifar Z, Fridoni M, Ghatrehsamani $M$, et al. Evaluation of the effects of pulsed wave LLLT on tibial diaphysis in two rat models of experimental osteoporosis, 
as examined by stereological and real-time PCR gene expression analyses. Lasers Med Sci. 2016;31(4):721-732. doi:10.1007/s10103-016-1916-9

19. Ebrahimi H, Najafi S, Khayamzadeh $M$, Zahedi A, Mahdavi A. therapeutic and analgesic efficacy of laser in conjunction with pharmaceutical therapy for trigeminal neuralgia. J Lasers Med Sci. 2018;9(1):63-68. doi:10.15171/ jlms.2018.13

20. Khalighi HR, Mortazavi H, Mojahedi SM, Azari-Marhabi S, Moradi Abbasabadi F. Low level laser therapy versus pharmacotherapy in improving myofascial pain disorder syndrome. J Lasers Med Sci. 2016;7(1):45-50. doi:10.15171/ jlms.2016.10

21. Wang CZ, Chen YJ, Wang YH, et al. Low-level laser irradiation improves functional recovery and nerve regeneration in sciatic nerve crush rat injury model. PLoS One. 2014;9(8):e103348. doi:10.1371/journal. pone. 0103348

22. Darabi S, Tiraihi T, Delshad A, Sadeghizadeh M, Khalil $\mathrm{W}$, Taheri T. In vitro non-viral murine pro-neurotrophin 3 gene transfer into rat bone marrow stromal cells. J Neurol Sci. 2017;375:137-145. doi:10.1016/j.jns.2017.01.058

23. Darabi S, Tiraihi T, Delshad A, Sadeghizadeh M, Taheri T, Hassoun HK. Creatine enhances transdifferentiation of bone marrow stromal cell-derived neural stem cell into GABAergic neuron-like cells characterized with differential gene expression. Mol Neurobiol. 2017;54(3):1978-1991. doi:10.1007/s12035-016-9782-9

24. Ghorabi MT, Aliaghaei A, Sadeghi Y, et al. Evidence supporting neuroprotective effect of adipose derived stem cells on PC12 cells against oxidative stress induced by H2O2. Cell Mol Biol (Noisy-le-grand). 2017;63(3):1-6. doi:10.14715/cmb/2017.63.3.1

25. Clementi ME, Pani G, Sampaolese B, Tringali G. Punicalagin reduces $\mathrm{H} 2 \mathrm{O} 2$-induced cytotoxicity and apoptosis in PC12 cells by modulating the levels of reactive oxygen species. Nutr Neurosci. 2018;21(6):447-454. doi:10. 1080/1028415x.2017.1306935

26. Sai Y, Wu Q, Le W, Ye F, Li Y, Dong Z. Rotenone-induced PC12 cell toxicity is caused by oxidative stress resulting from altered dopamine metabolism. Toxicol In Vitro. 2008;22(6):1461-1468. doi:10.1016/j.tiv.2008.04.019

27. Jiang B, Liu JH, Bao YM, An LJ. Hydrogen peroxideinduced apoptosis in pc12 cells and the protective effect of puerarin. Cell Biol Int. 2003;27(12):1025-1031.

28. Zhou LJ, Zhu XZ. Reactive oxygen species-induced apoptosis in PC12 cells and protective effect of bilobalide. $J$ Pharmacol Exp Ther. 2000;293(3):982-988.

29. Tang XQ, Chen J, Tang EH, Feng JQ, Chen PX. Hydrogen peroxide preconditioning protects $\mathrm{PC} 12$ cells against apoptosis induced by oxidative stress. Sheng Li Xue Bao. 2005;57(2):211-216.

30. Tahmasebinia F, Pourgholaminejad A. The role of Th17 cells in auto-inflammatory neurological disorders. Prog Neuropsychopharmacol Biol Psychiatry. 2017;79(Pt B):408416. doi:10.1016/j.pnpbp.2017.07.023

31. Tang XQ, Feng JQ, Chen J, et al. Protection of oxidative preconditioning against apoptosis induced by $\mathrm{H} 2 \mathrm{O} 2$ in PC12 cells: mechanisms via MMP, ROS, and Bcl2. Brain Res. 2005;1057(1-2):57-64. doi:10.1016/j. brainres.2005.07.072

32. Xiao-Qing T, Jun-Li Z, Yu C, Jian-Qiang F, Pei-Xi C. Hydrogen peroxide preconditioning protects $\mathrm{PC} 12$ cells against apoptosis induced by dopamine. Life Sci. 2005;78(1):61-66. doi:10.1016/j.lfs.2005.04.048

33. Ammar TA. Monochromatic infrared photo energy versus low level laser therapy in chronic low back pain. J Lasers Med Sci. 2015;6(4):157-61. doi: 10.15171/jlms.2015.11.

34. Son JH, Shim JH, Kim KH, Ha JY, Han JY. Neuronal autophagy and neurodegenerative diseases. Exp Mol Med. 2012;44(2):89-98. doi:10.3858/emm.2012.44.2.031

35. Hua P, Liu LB, Liu JL, et al. Inhibition of apoptosis by knockdown of caspase- 3 with siRNA in rat bone marrow mesenchymal stem cells. Exp Biol Med (Maywood). 2013;238(9):991-998. doi:10.1177/1535370213497320

36. Farivar S, Malekshahabi T, Shiari R. Biological effects of low level laser therapy. J Lasers Med Sci. 2014;5(2):58-62.

37. Fekrazad R, Asefi S, Allahdadi M, Kalhori KA. Effect of photobiomodulation on mesenchymal stem cells. Photomed Laser Surg. 2016;34(11):533-542. doi:10.1089/ pho.2015.4029

38. Thunshelle C, Hamblin MR. Transcranial low-level laser (light) therapy for brain injury. Photomed Laser Surg. 2016;34(12):587-598. doi:10.1089/pho.2015.4051

39. Ando T, Sato S, Kobayashi H, et al. Low-level laser therapy for spinal cord injury in rats: effects of polarization. J Biomed Opt. 2013;18(9):098002. doi:10.1117/1.jbo.18.9.098002 